\title{
Women, Puberty Rites and Heterosexuality: A Case Study in Côte D'Ivoire
}

\author{
Toure Irafiala \\ Communication and Change Organization Laboratory, University Alassane Ouattara, Bouake, Cote d'Ivoire
}

\section{Email address:}

martinet20091@live.fr

\section{To cite this article:}

Toure Irafiala. Women, Puberty Rites and Heterosexuality: A Case Study in Côte D'Ivoire. World Journal of Public Health. Special Issue: Women, Health and Sustainable Development in Under Developed Country. Vol. 6, No. 1, 2021, pp. 1-5. doi: 10.11648/j.wjph.20210601.11

Received: April 20, 2020; Accepted: December 30, 2020; Published: January 19, 2021

\begin{abstract}
Since 2000 the International Community has focused on the promotion of women with actions and recommendations on gender equality between men and women and empower women. On closer analysis, Millennium Development Goal does not explain the status of women in reproducing society through heterosexuality in which women are in a position of power. The theoretical debate on heterosexuality feeds two contradictory positions, one considering it as natural because of the natural state of the sexes, man and woman, and the other modulating its argument by a cultural construction. From the cases of observation and analysis of the "Famian Blâ" puberty rites of Baoulé Iffou and "Yikèè" of Toura, women are configured in heterosexual relationships. Women are recognized by society as queen mothers or social generators and are culturally and biologically empowered to procreate and sustain the human species. The cultural symbolism of pubertal rites is to confer girls and thus women a social status through heterosexuality. But heterosexuality falls into a form of cultural constructivism with the development of forms of sexuality supported by the promotion of human rights. Homosexuality and other forms of sexual practices undermine the reproductive status of society supported by cultural symbolisms rites. The cultural symbolism of pubertal rites is to confer girls and thus women a social status through heterosexuality.
\end{abstract}

Keywords: Woman, Rites, Heterosexuality, Cote d'Ivoire

\section{Introduction}

In 2000, the international community adopted on the Millennium Development Goals, and recommended in the objective 5 "Achieve gender equality and empower all women and girls" [1]. The projected millennium goal beyond 2015 is supported by education for women's empowerment, "Education can empower women to overcome forms of gender discrimination so they can make more informed choices about their lives. Such empowerment benefits women but also benefits the living conditions of their children and strengthens society". On closer analysis, Millennium Development Goal 5 does not explain the status of women in the reproduction of society [2], or heterosexuality, or she could be in a governing position. The theoretical debate on heterosexuality feeds two contradictory positions, one considering it as natural due to the natural state of the sexes, man and woman [3-5] and the other modulating its arguments through a cultural construction. This contradictory debate on heterosexuality is only one ingredient of the classic debate on the opposition between nature and culture, the innate and the acquired. The reflection inspired by a text in progress, does not pretend to settle the debate and neither does it line up exclusively in one position to the detriment of the other. By the subject "woman, pubertal rites and heterosexuality of relationships: case study in Ivory Coast", it is a question of demonstrating that the perception of the sex of women as a biological factor drives the pubertal rite and consecrates relationships heterosexual. The celebration of the choice of the rite "Famain Bla" among the Baoulé Iffou and "Yikèè" among the Toura indicates objects of anthropological observation. How is the process that describes the logical relationships between "woman, puberty rites and heterosexual relationships: the case of Côte d'Ivoire" presented? The state of the biological sex of the woman causes the pubertal rites which consecrate the heterosexual relations between the man and the woman. 


\section{Method}

\subsection{Investigation Site}

Ethnocultural pubertal rites are variously experienced in the Gour, Krou, Akan Lagunaires, Mandé du Nord, Mandé du Sud and Akan Continentaux ethnocultural areas in Côte d'Ivoire [6]. But the reflection in progress, chooses to observe the puberty rites with and / or without body marking [7] experienced by the Continental Akan and the Mandé of the North. The "Famian blâ" rites in Baoulé Iffou country and "Yikèè" in Toura country are respectively located in the Iffou Administrative Regions in the Center-West and Tonpki in the West of Ivory Coast. The rites celebrate and dedicate the passage from childhood to the exercise of sexual authority and the culture of heterosexuality.

\subsection{Data Collection Technique and Theories of Analysis}

The choice of documentary technique makes it possible to browse ethnographic bibliographic references. In June 2019, an interview guide was organized with resource persons from the Iffou and Toura cultural areas and the assistance of investigators to enrich information relating to pubertal rites and their symbolic interference in heterosexual relationships.

Manual processing was favored in the processing and analysis of documentary and ethnological data. The combination of both content analysis and phenomenological analysis highlights the symbolism of sexual intercourse which passes through the pubertal rites determined by the woman.

From the choice of socio-anthropological places to the identification of techniques / data collection and analysis, it is a question of having data on the unfolding of the pubertal rites "Famian blâ" and "Yikèè".

\section{Result}

\subsection{The "Famian blâ" Rite in Baoulé Iffou Country}

The pubertal rite "Famian blâ" consecrates "the reproductive status of the pubertal girl 'Taloua ba' in society" [8] according to the following stages: the announcing semiology, the purifying act, the community meal, confession, and call for candidates.

\subsubsection{The Warning Semiology}

Two main signs are observed:

Body signs: enlargement of the breasts, hair on the private parts, etc.

Symbolism of purification: "Manzakuia".

By noticing the enlargement of the breasts and the presence of hair on the private parts, "Taloua ba" became the subject of particular attention. She is assigned to the vigilance of another woman "Blâ kpin gbin", who has over time proven to be a generous woman and a virtuous mother, to confirm the menses "Manzakuia". The required confirmation triggers the purifying protocol.

\subsubsection{The Purifying Act}

"Taloua ba" is subject to an act of purification: "Blâ wunziwa", that is the washing of women, purified women, and adults. The observation of the appearance and flow of blood during the menses, the symbolism of red color justifying a change boosts the purifying act by a presence of white color. Indeed, on a bright day in the reproductive health calendar and in the early hours of the morning, "Taloua ba" receives a white cloth with a surprised jet of "Blâ kpin gbin". There follows a brutal awakening from sleep. This brutal jet of white tissue can cause watery eyes in the pubertal adolescent. Otherwise, she can be hit with chicory to symbolically get tears in her eyes. The flow of blood is marked by the "Manzakuia", which is the throwing of the white cloth of "Blâ kpin gbin" by surprise. Also, the symbolism of the tears of "Taloua ba" constitutes the purifying act "Blâ wunziwa". It involves the transition from puberty from "Taloua ba" to the status of social maturity. Furthermore, "Blâ wunziwa" opens at a community meal event.

\subsubsection{The Community Meal}

The day after the brutal awakening, "Taloua ba" shares with the other girls of her generation a meal composed of corn seeds and fines of dry roasted peanuts. Through the communion meal between "the chosen ritual" and the other "Taloua ba", divorce is consumed with childhood on the one hand and access to a new status, which is that of reproduction on the other hand. The sketch in another statute in the society requires of "Taloua ba" a community accompaniment for the quest for longevity and success which are aggregated in the expression "Moayè".

\subsubsection{The Call for Candidates}

"Atonvle" is the rite of celebration of the beauty of "Taloua ba".

Taloua ba" is installed on the "Cessè bia", which means royal stool. It is clad in the canons of "beauty and aesthetics"[9]: royal hairstyle, naked body coated with palm oil, "adornments"[10], sex cover, and feet in the royal sandals placed on animal skin. Investing in the status of "Famian blâ" on the royal stool, the initiate enjoys a social and popular anointing, congratulations/encouragement accompanied by donations/gifts and especially loincloths by family and community members. During the other days of the ritual, "Famian blâ" accompanied by maids of honor, pass from court to courtyard of the village to execute the protocol of greetings and recognition. At the end of the "Atonvlè" rite, "Taloua ba" is subjected to the test of virginity.

\subsubsection{The Confession}

The initiate is subjected to an interrogation on the state of her virginity or not before the ritual. When virginity is confirmed, the locks on the doors of virginity give way to training on sex, the sacred power of women, the exercise of sexual activity, marital, and family lives. The suitors embark on the protocols of sexual, marital, and family negotiations. In the event that virginity is overturned, fines are imposed on 
guilty men by way of redemption of the happiness which the ritual "Famian blâ" confers on women and their children, whether born or unborn.

The "Famian blâ" rite illustrates the symbolism of the transition from the state of childhood to "adult life" [11] of "Taloua ba" for access and exercise of female reproductive status in society. But in Toura country, the pubertal rite is differently modulated.

\section{2. "Yikèè" Puberty Rite with Body Marking Among the Mandé du Nord: Toura}

The Toura or wi / wen ethnic group is made up of nine [12] cantons: Gouorsèè, Guousèè, Gansèè, Walousèè, Yiliguélésèè, Liwaasèè, Nanhosèè, Boorsèè, and Gwagnsèè who experience annual cultural hikes "Yadélé", "Gbon" and "Yikèè" [13]. The initiation rite "Yikèè" gives rise to both the male and female novices, the test of social maturation, according to the following stages: the semiology announcing, the vigil of statements of choreographic talents, seclusion in sacred forests, the confirmation dance or choreographic exploits, and the pregnancy dance.

\subsubsection{The Predictive Semiology}

The "Yikèè" rite designates female and male initiations in Toura. It is not a question of confirming the resilience of a cultural fact which undermines human dignity, in particular the girl child. Thus, the reference to the cultural rite "Famian blâ" or "Yikèè" retains the symbolism which it develops and which can generate educational recovery through various forms.

The State of the "Soï" Boy

The bodily signs are revealed by the presence of hairs on the intimate parts of the body, in particular the chin, armpits, and pubis. The voice takes on an air of gravity, a sign foreshadowing the expression of authority. Checking for these signs subjects "Soï" to the act of circumcision. Scarring is usually done after a week. Semiological reading is observed in girls of the same generation.

The State of the "Soï" Girl

Two main signs can be seen in the state of "Soï" girl:

Body signs: enlargement of the breasts, hair on the private parts;

Symbolism of purification: the red blood of menstruation "Men yé".

The trigger for the "Yikèè" rite comes from girls and, by analogy, the recruitment of promoter boys follows suit. So the girl impels the ritual tone "Yikèè" among the Toura.

\subsubsection{The Vigil of Statements of Choreographic Talents}

The novice is called to invest in the preparations for "Yikèè": collection and storage of firewood, husking and rice storage, sewing of clothing, hairstyle model "Kàlà"... The states "Soï" for the boy with circumcision and for the girl with the preparations open to the organization of a dance vigil "Yignan". "Yignan" is that occasion where both partners (boy and girl) express their choreographic talents. The next day is the departure for the sacred woods.

\subsubsection{Seclusion in the Sacred Forests}

The time of seclusion in sacred groves can extend over a week. The "Soï" boys access the sacred wood "Soïgngui" where they successively receive human training from the large mask "Guéhéwaa", from the panthers "Logno" and "Gbon". The "Soï" girls have access to "Kognpélé" where they undergo the excision which gives them the status of "Bâ nein" and remain under guardianship matrons and educators for both care and training: hygiene, sexuality, choreographic dances, education, married and family life.... The initiate "Bâ nein" answers a question about the state or not of her virginity. At the end of the seclusion period, she attains the status "Bâ woloe" and prepares for the evening "Yikèè" dedicating the return to the community.

\subsubsection{The Confirmation Dance or Choreographic Exploits}

The return of initiates is consecrated by a choreographic demonstration in the public place "Guié é téné" or a confirmation dance and choreographic exploits of the "Yikèè". The following table shows the changes in the designation of social age between the novices and the "Yikèè".

Table 1. Social hierarchy of social status from the "Yikèe” rite.

\begin{tabular}{lll}
\hline Quality of the elder & Before «Yikèè & After «Yikéé» \\
\hline Big Brother & «Dohn» & "Doh wan» \\
Big sister & «éi» & ¿Déi maan» \\
\hline
\end{tabular}

Source: Survey data, June 2019

If at the dance "Yignan", it is the partners "Dohn" and "Déi" who perform with the status of "Soï", on the return from the sacred forests, the "Yikèè" are respectively designated by "Doh wan" and "Déi maan" at the choreographic sessions of "Guié é téné". The "Doh wan" and "Déi maan" are called upon to demonstrate exploits and confirm the choreographic potentials. In the second choreographic performance in the public square, the "Doh wan" and "Déi maan" dance face to face, thereby transgressing the parallelism of relational relationships in favor of an encounter between two complementary sexes to perpetuate the human and community kingdoms. The two sexes are configured in logic relationships of complementarity and verticality. The "Yikèè" approach sex life, marriage, and family relationships according to the rules of the Toura community.

\subsubsection{The Pregnancy Dance}

The girl "Soï" who infects the state of virginity is affected by a dance called "Gwitan". It is organized by girls of initiation age, in the evenings, through songs like:

"She who becomes pregnant in her "Soil" state does not benefit from good tamtam sounds!"

"I throw a pregnancy stone, she misses me to touch $n$ [the name of the pregnant "Soï" or having violated virginity]". To end the generational and ritual taunts, the dishonored parents and family members brush the incestuous girl with kaolin and invite her to join the culturally provocative group. The "Yikèè" rite through circumcision and excision of the "Soï" 
configure the two sex partners in reproductive health and social responsibility.

Childhood continues to be observed through the crossing of pubertal rites for reproductive health, of reproductive society especially by the maturation of social status. The "Famian blâ" rites of the Baoulé Iffou and "Yikèè" of the Toura bear witness to this symbolism which, through forms stolen from rural and urban areas, continues to be practiced despite the struggles and policies of ostracism. Can we eradicate culture with cannons, even of the latest technological caliber? Consciously or unconsciously, the girl and the boy remain under an initiation embargo in favor of the quality of a reproductive society when the school opens the doors to them.

\section{Discussion}

Women are at the heart of puberty rites and heterosexual relationships. What is the anthropological significance?

\subsection{From Myth to Female Reality Through Sex}

Male and female initiations and sacred dances make the sex of women a myth. At the last level of the initiation into Poro, it is the image of a woman who is presented at Kahafolo. Because women give life, they have power over the world and in the governance of the organization.

The examination of the ethnographic results on the status of women in the "Famian Blâ" and "Yikèè" puberty rites are part of a cultural logic but which takes its meaning from a biological reality: the differentiated male and female sex.

\subsection{For or Against Pubertal Rites}

In Ivorian ethnocultural spheres, symbolism marks the rite of passage from puberty to social maturity, from childhood to adolescence.

The transfer of power to the Age-Class Communities also reveals the practice of this symbolism, even if the rituals are not to be confused. The dimension of the sacred is therefore decisive in the process of socialization and the exercise of social responsibility. If the rites of puberty without body marking are not the subject of particular attention of observers, those who denote a genital mutilation in pubertal girls are denounced, criticized and considered as "violence against women" [14].

Indeed, a dominant ideology which takes its bearings from the feminist movement has widened its object of struggle to questions of gender, to so-called 'unworthy' practices (early marriages, forced marriages, ill-treatment of girls and women, bombing to the physical and moral integrity of the girl and the woman by the excision... If one can note advances related to organizational and pleading (multilateral, bilateral, NGO and associations), legal (Laws, decrees...), criminal... a careful observation remains to operate on the cultural dimension which orchestrates practices, habits and traditions which find it difficult to follow the evolution of time, because they are bludgeoned to disappear. Can we make disappear a culture without spirit of discernment allowing before distinguishing the tares from the wheat? With reference to a form of cultural resilience [15].

This author [16] represents the presence of excision practices which occupant the whole northern part of Côte d'Ivoire and the mountainous west.

\subsection{Women and Traditions of Heterosexual Relationships: Quit or Double}

The practice of the "Famian Blâ" and "Yikèè" puberty rites put women at the heart of heterosexual traditions by virtue of their sexual and biological status with the aim of perpetuating the descendants of the socio-cultural species. But research is trying to show that heterosexuality cannot be seen as the basis of culture. Indeed, if heterosexuality is universal, heterosexual culture is not. It shows that even if biological reproduction is heterosexual, Indo-European society does not form a heterosexual society. Suddenly heterosexuality is brought back to the liking of relativism and is part of a cultural construction like the other forms of homosexuality which one meets more and more in modern society especially encouraged by policies of inclusion of minorities [16] in the sustainable development process [17].

\section{Conclusion}

The woman at the heart of the "Famian Blâ" puberty rites in Baoulé country and "Yikèè" in Toura country bears the signs of heterosexuality which confirm and cultivate the reproductive relationships between men and women. Also heterosexuality takes on meaning from the cultural status of women. Heterosexuality escapes from the power conferred on women by puberty rites to fall into a form of cultural constructivism with the development of forms of sexuality supported by the promotion of human rights.

\section{References}

[1] UNESCO, EFAGMR and GLOBAL EDUCATION FIRST INITIATIVE (2014) Sustainable Development Begins with Education, How Education can contribute to the proposed post-2015 goals. Paris, 1-24.

[2] Wellings K, Palmer MJ, Geary RS, et al. «Changes in conceptions in women younger than 18 years and the circumstances of young mothers in England in 2000-12: an observational study». Lancet 2016; published online May 23. http://dx.doi.org/10.1016/S0140-6736(16)30449-4. Accessed 12 December 2020.

[3] P. Awondo; P. Gishier; G. Reid; G.; A. Jaunait; A. Le Renard; E. Marteu (2012) «Homophobic Africa? Towards a More Nuanced View», African Studies Review, vol. 55, no 3, December 2012, p. 145-168.

[4] S. Freud (2014) Three essays on sexual theory, Small Library, PAYOT, Paris.

[5] L. Tin, L. Georges (2012) "The invention of heterosexuality" in HUMAN MAGAZINE SEXUAL IDENTITIES, Monthly, $\mathrm{N}^{\circ} 235$. 
[6] J. L. Loucou (2002) History of the Ivory Coast: peoples and ethnic groups, Editions NETER, Abidjan, 200 pages.

[7] N. F. Kouakou (1983) "African scarifications and their transparency in socio-cultural affinities" in Annals of the University of Abidjan, Series F, Volume XI Ethnosociology, University of Abidjan, pp 13-25.

[8] Tanoh, N. A. E. (2019) "Les déterminants sociologiques des risques accrus de la maternité précoce dans le District sanitaire de Daoukro/Région de Iffou au centre-est de la Côte d'Ivoire", Thèse de Doctorat Unique Nouveau Régime en SocioAnthropologie de la Santé, Université Alassane Ouattara, Bouaké, Côte d'Ivoire, 300 pages.

[9] K. Konan (1978). Sculpture and the meaning of Baoulé art. In: Annals of the University of Abidjan, Series F, Volume VII, Ethnosociology: University of Abidjan; 33-35.

[10] K. Konan (1983). The Akan aesthetic. In Annals of the University of Abidjan, Series F, Tome XI Ethnosociologie. University of Abidjan; 5-12.

[11] A. Boa, I. Touré and N. F. Kouakou (2019). Rites, time and procreation among the Lobi of Bouna (Ivory Coast). In Kasa Bya Kasa Ivoirian Journal of Anthropology and Sociology; (42) $25: 18-30$

[12] I. François-André and B. Holas (1963). The Toura, a mountain civilization from Côte d'Ivoire. In: Archives of sociology of religions; 15: 186 .
[13] Ministry of Higher Education and Scientific Research (2008). Teacher training to promote the abandonment of female genital mutilation: collection of reading notes on female genital mutilation (FGM). Second Edition, Burkina Faso; 1142 .

[14] UNFPA (2014). "Pregnancy among school-aged adolescents in Côte d'Ivoire: the government and UNFPA are tackling the scourge". [http://wcaro.unfpa.org/fr/news/pregnancy-at-teengirls-scolaris $\% \mathrm{C} 3 \% \mathrm{~A} 9$ es-en-c $\% \mathrm{C} 3 \% \mathrm{~B} 4$ te-

d\%E2\%80\%99ivoire-le-government-et-1\%E2\%80\%99unfpa-s] October 15, 2017.

[15] N. A. N'Doumy (2007). "Procreation, symbolism and reproductive health in Black Africa south of the Sahara: the case of the Baoulé group in Côte d'Ivoire", Thesis of State Doctorate Ès-Letter and Human Sciences Humaines, Bouaké, University OUATTARA (Formerly Bouaké University).

[16] L. R. A. Oulaye (2019) "Attempts at visualization and selffulfillment of the Ivorian FSF" in REVUE LE CAÎLCEDRAT Canadian Review of Philosophy, Letters and Human Sciences, N008, Les Editions Différance Pérenne, Quebec, Canada, pp 71-84.

[17] UNESCO, IEA TIMSS. Measuring global education goals: How TIMSS help Monotoring progress Towards Sustainable Development Goal 4 Using TIMSS (Trends in International Mathematics and Science Study). Paris, 2019; 1-16. 